\title{
ネットワーク構造の自己選択能力を備えたニューラルネットワークと 光の非線形システム同定への応用
}

\author{
近 藤 正* \\ Neural Network with a Self-Selection Ability of Network Structure \\ and Its Application to Nonlinear System Identification
}

Tadashi Kondo*

\begin{abstract}
A neural network which has a self-selection ability of network structure is described. This neural network algorithm is a revised one of the neural network which can identify a nonlinear system whose structure is very large and complex. By using a criterion based on a prediction error, a neural network structure which is adapted for a complexity of a nonlinear system can be selected automatically. This neural network is applied to an identification problem of a rolling model and a physical and neural network combined model is identified. It is shown that the physical and neural network combined model gives better prediction results as compared with a conventional physical and statistical combined model.
\end{abstract}

Key Words : neural network, nonlinear system identification, GMDH, self-selection, rolling model

\section{1. まえがき}

近年，ニューラルネットワークの研究が活発に行われ て，その成果がいろいろな分野に応用されている(1) かしながら，ニューラルネットワークを実際問題へ応用 する場合，対象分野の違いにより構成すべきニューラル ネットワークの構造や規模が大きく異なるために，対象 分野に適したニューラルネットワークの構造を見つけだ して, 実用的な汎化能力を備えたニューラルネットワー クを構成することは非常に難しい.このことがニューラ ルネットワークを実際問題へ応用した場合に，十分な成 果を上げられない 1 つの理由になっている. 対象分野か ら得られる入出力デー夕を学習することにより, ニュー ラルネットワークの最適構造を自動的に自己組織化する 構造同定に関する研究が活発に行われているが，まだ有 力な理論が確立されておらず，現在はおのおのの分野を 対象にして個別に応用のための研究がなされているのが

\footnotetext{
* 徳島大学医療技術短期大学部 徳島市蔵本町 3-18-15

* School of Medical Sciences, The University of

Tokushima, Tokushima

(Received November 11, 1994)

(Revised April 14, 1995)
}

現状と思われる.

本研究では，まず対象分野に適したネットワーク構造 を自己選択する能力を備えたニューラルネットワークに ついて述べる.このニューラルネットワークは，複雑な 構造をした非線形システムの同定を目的としたニューラ ルネットワーク4) 7) のアルゴリズムにネットワーク構造 の自己選択能力を付け加えたもので，予測誤差を評価規 準として用い少ない学習計算量により対象分野に適した ニューラルネットワーク構造を自己選択することが可能 である．本研究で用いたニューラルネットワークの自己 選択方法は, 従来から提案されているような, 個々の ニューロンの特性に注目した生成的学習方法や3) 削除的 学習方法 ${ }^{3)}$ などを行ってニューラルネットワークを自己 形成させるニューラルネットワークの構造同定方法とは 異なり，ここでは非線形システムの同定を目的とした ニューラルネットワークに含まれている設計パラメータ (量子化係数や学習回数など)を変化させることにより, より少ない学習計算量でいくつかのニューラルネット ワーク構造を連続的に発生させて, その中から汎化能力 のより大きなニューラルネットワーク構造を自己選択す るという方法を用いている。このために, 実際問題への 応用を目的とした大規模なニューラルネットワークを構 
成する場合などにおいて, より少ない学習計算量で自動 的に汎化能力の大きなニューラルネットワークを構成す ることができる.このニューラルネットワークの実際問 題への応用として, 圧延モデルの同定問題へ適用しその 実際問題への有効性を明らかにする。

\section{2. ネットワーク構造の自己選択能力を}

\section{備えたニューラルネットワーク}

ネットワーク構造の自己選択能力を備えたニューラル ネットワークについて述べる.ニューラルネットワーク を実際問題へ応用する場合，ニューラルネットワークの 構造やその規模がニューラルネットワークの汎化能力に 大きく影響を及ぼすために，これらのニューラルネット ワークの構造や規模をどのように決定するかが重要な問 題となる. 本研究で用いるニューラルネットワークは, 少ない学習計算量により, 対象システムに適したニュー ラルネットワークの構造と規模を自己選択する能力を もっている.このために, 複雑な構造をした非線形シス テムの同定を目的としたニューラルネットワーグ) 7) 実システムの同定問題へ応用する場合に行っていたよう に,ニューラルネットワークの設計パラメータ(量子化係 数や学習回数など) を変更して,かなりの回数ニューラル ネットワークの学習計算を繰り返して, 適切なニューラ ルネットワークの構造と規模を見つけだすという操作が 不必要になり, 本研究で用いるニューラルネットワーク に関する専門知識がなくても，実システムの同定問題に 対して, 少ない学習計算量で実用的な予測精度をもつ ニューラルネットワークを容易に構成できる。まずはじ めに, 本研究で用いるニューラルネットワークの構造に ついて述べる.

\section{1 ニューラルネットワークの構造}

本研究で用いるニューラルネットワークは，4層から なる階層型ニューラルネットワークをしており，以下に 各層の入出力関係を示す.

\section{<第 1 層 $>$}

$$
u_{j}^{1}=x_{j} \quad(j=1,2, \cdots, p)
$$

ただし, $x_{j}(j=1,2, \cdots, p)$ はシステムの入力変数, $u^{1}{ }_{j}$ は 第 1 層に抢ける $j$ 番目のニューロンの出力値を示す.

\section{$<$ 第 2 層 $>$}

$$
\begin{aligned}
& z_{h}^{2}=\sum_{i} w_{i h}^{1}{ }_{h}^{2} \cdot u^{1}{ }_{i}+\sum_{i} \sum_{j} w_{i j}^{1}{ }_{i j}^{2} \cdot u_{i}^{1} \cdot u_{j}^{1}-w_{0}^{1}{ }_{0}{ }_{h} \cdot \theta^{1}{ }_{0} \\
& u^{2}{ }_{h}=\frac{1}{\left\{1+\exp \left(a\left(\left|z^{2}{ }_{n}\right|-K / 2\right)\right)\right\}}
\end{aligned}
$$

ただし， $\theta^{1}{ }_{0}=1, K$ は量子化係数, $w^{1}{ }_{i}{ }^{2}{ }_{h}$ は, 第 1 層の $i$ 番目のニューロンと第 2 層の $h$ 番目のニューロンとの
結合荷重値, $w^{1}{ }_{i j}{ }^{2}{ }_{h}$ は, 第 1 層の $i$ 番目のニューロンと第 1 層の $j$ 番目のニューロンおよび第 2 層の $h$ 番目の ニューロンとの非線形結合 (2 次結合)荷重值を示す。 た, $w_{0}{ }^{2}{ }^{2}$ は第 2 層の $h$ 番目のニューロンに対する閾値 を示す. $a$ は量子化に用いる釣り鐘状関数の形状を決め るパラメータを示す. $z^{2}{ }_{h}$ は第 2 層の $h$ 番目のニューロ ンへの入力の総和を示す.

\section{<第 3 層 $>$}

$$
\begin{aligned}
z_{j}^{3} & =\sum_{i} w_{i j}^{2}{ }^{3} \cdot u^{2}{ }_{i}-w_{0{ }_{j}}{ }^{3} \cdot \theta_{0}^{2} \\
u_{j}^{3} & =\frac{1}{1+\exp \left(-z_{j}^{3}\right)}
\end{aligned}
$$

ただし, $\theta^{2}{ }_{0}=1$ である. $w^{2}{ }_{i j}{ }_{j}$ 壮第 2 層の $i$ 番目のニュー ロンと第 3 層の $j$ 番目のニューロンとの結合荷重値, $w^{2}{ }_{0}{ }_{j}{ }_{j}$ は第 3 層の $j$ 番目のニューロンに対する閾值を示 す. $z^{3}{ }_{j}$ は第 3 層の $j$ 番目のニューロンへの入力の総和を 示す.

\section{$<$ 第 4 層 $>$}

$$
\phi_{j}=\sum_{i} w_{i j}^{3}{ }^{4} \cdot u^{3}{ }_{i} \quad(j=1,2, \cdots, q)
$$

ただし, $w^{3}{ }_{i j}{ }_{j}$ は第 3 層の $i$ 番目のニューロンと第 4 層 の $j$ 番目のニューロンとの結合荷重値を示す.

本ニューラルネットワークでは, 第 2 層において入力 変数の非線形結合とその量子化を行っている. 第 3 層に お $w^{3}{ }_{i j}{ }_{j}$ はバックプロパゲーション法を用いて学習させる. 本ニューラルネットワークにおける基本的な考え方は, ネットワークの階層構造を CMAC (Cerebellar Model Arithmetic Computer $)^{8)}$ の考え方を適用して自己選択 し，ネットワークに含まれるパラメータ(結合荷重)は バックプロパゲーション法を用いて学習させることであ る.ここで，第 2 層のパラメータ (結合荷重)もバックフ ロパゲーション法を用いて学習させることが可能である が，(3)式に含まれる絶対值の処理アルゴリズムが必要 になるために，本研究ではバックプロパゲーション法に よる第 2 層のパラメータの学習は行わない. 第 2 層と第 3 層に扔けるニューロン数,さらに, 第 2 層における結合 荷重 $w^{1}{ }_{i}{ }^{2}, w^{1}{ }_{i j}{ }^{2} h, w^{1}{ }_{0}{ }^{2}{ }_{h}$ の值および第 3 層における結合 荷重 $w^{2}{ }_{i}^{3}{ }_{j}, w^{2}{ }_{0}{ }^{3}{ }_{j}$ の初期値を CMAC の考え方を用いて決 定する. Fig. 1 に，ニューラルネットワークの構造を示 す.つぎに，本ニューラルネットワークの各層における 情報処理について述べる。

\section{2 ニューラルネットワークにおける情報処理}

まず，本研究で使用するニューラルネットワークと CMAC との対応について述べる.ニューラルネットワー クの第 2 層のニューロンは, CMAC の苔状線維 $(m)$ に 信号を与える起始細胞に対応させ，第 3 層のニューロン 


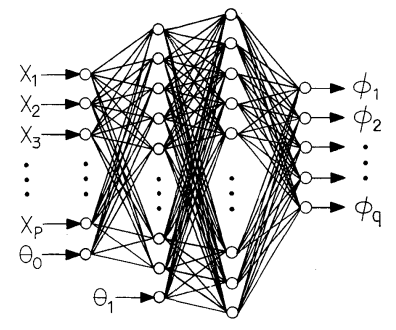

Fig. 1 Structure of the neural network

は CMAC の顆粒細胞 $(A)$ に対応させる.さらに, 第 4 層 のニューロンは CMAC のプルキンエ細胞 $(P)$ に対応さ せる，このように対応づけることにより，CMACの考え 方を適用することができる，各層における情報処理は以 下のようになる。

\section{＜第 1 層における情報処理 $>$}

第 1 層では, 入力変数の值を第 2 層のニューロンにそ のまま出力する.このために，第 1 層におけるニューロ ンの個数は閾值を出力するニューロンとあわせて（入力 変数の個数+1) となる. 本研究で用いるニューラルネッ トワークでは，まだ最適な入力変数を自己選択する能力 を備えていないために，入力変数は対象分野の知識に基 づいて決定したり，あるいはヒューリスティックスに入 力変数を決定する方法を用いる。しかしながら，不必要 な変数を入力変数としてネットワークの内部に取り込む とネットワークの規模が不必要に大きくなり，学習計算 量が増加したり，ネットワークの汎化能力が劣化するた めに，不必要な変数はできるだけ入力変数として用いな いように，事前に十分に検討する必要がある.

\section{<第 2 層における情報処理 $>$}

第 2 層における情報処理は, CMACにおいて入力べク トル $(S)$ から苔状線維 $(m)$ への情報処理に対応する.つ まり，(2)式により入力変数とその非線形結合により, 複数の入力ベクトル $(S)$ を作成する。つぎに，作成した 入力ベクトルごとに，(3)式によりその量子化を行う. ( 3 ) 式の出力は, 第 3 層において複数個組み合わされて, 顆粒細胞 $(A)$ への入信号となる.このために, 第 2 層 のニューロンの個数は, 第 3 層の顆粒細胞へ信号を伝達 する苔状線維の起始細胞の個数に一致する.Fig. 2 に, 入 カベクトル $(S)$, 苔状線維を表わす集合 $(m)$, 顆粒細胞を 表わす集合 $(A)$ の関係を示す，図より，苔状線維を表わ す集合 $\left(m_{i}\right)$ は入力ベクトル $\left(S_{i}\right)$ を量子化することによ り構成された $(K \times r)$ 個の苔状線維の集合から構成され る. 図中の記号 $n^{i}{ }_{j}$ は苔状線維に付けた番号を表わす.ま た，記号 $K^{*}$ は入力ベクトル $(S)$ を量子化する場合の量 子化間隔を表わしており, $K^{*}=K \times \Delta S$ となる. $K$ は量

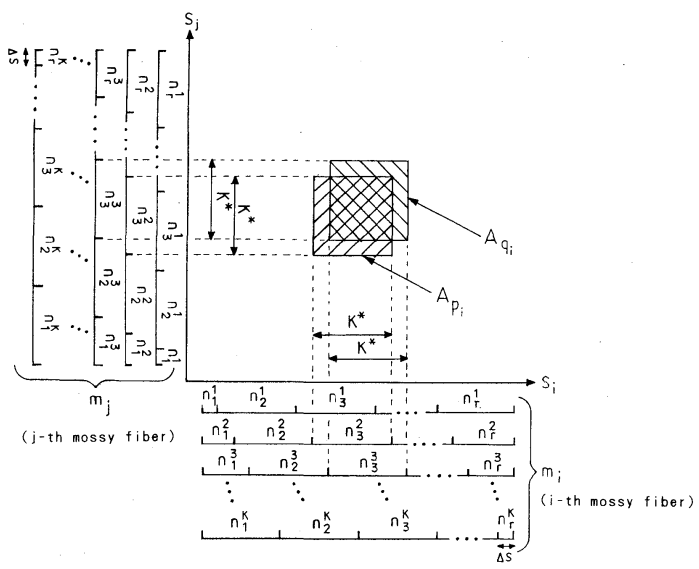

Fig. 2 Relationship between mossy fiber $(m)$ and granule cell $(A)$

子化係数, $\Delta S$ は量子化の最小間隔を示す. 量子化係数 $K$ の值を変化させることにより, 苔状線維の集合 $(m)$ の個 数が変化し, 結果として第 3 層の顆粒細胞 $(A)$ の個数が 変化する.このために，本研究で用いたニューラルネッ トワークでは，Kの值を変化させることにより，第 2 層 と第 3 層のニューロンの個数を容易に変化させることが でき， $K$ を構造パラメータとして用いることにより対象 となるシステムの複雑さに適したニューラルネットワー クの構造を自己選択することができる. 構造の自己選択 能力については後で詳しく述べる. また, Fig. 1 と Fig. 2 の対応については, Fig. 1 の第 2 層に抢けるニューロン は (2) 式と (3) 式の計算により, Fig. 2 の入力ベクトル $(S)$ から苔状線維 $(m)$ への情報処理を行っており，（3） 式の出力信号 $\left(u^{2}{ }_{n}\right)$ は苔状線維 $(m)$ からの出力信号を 模擬している.

\section{<第 3 層における情報処理 $>$}

第 3 層における情報処理は, CMAC の苔状線維 $(m)$ から顆粒細胞 $(A)$ への情報処理に対応させる.つまり, (4) 式により第 2 層のニューロンの出力を複数個組み合 わせて, 第 3 層のニューロンの入力とする.そして, (5) 式により入力信号の強さがある閾值を超えた場合, 出力 信号を発生させる. 第 3 層のニューロンの個数は顆粒細 胞の個数に一致する.つまり, 第 2 層の二ューロンの出 力の組合せ方法を決めることにより, 第 3 層のニューロ ンの個数と結合荷重の初期值が決まる.ここで, 第 2 層 のニューロンの出力の組合せ方法としていろいろな方法 が考えられるが, CMACにおいて相異なる 2 組の入力心゙ クトルを組み合わすようにニューラルネットワークの 第 2 層のニューロンの出力を組み合わせると汎化能力が 大きくなる.また, Fig. 1 と Fig. 2 の対応については, 
Fig. 1 の第 3 層のニューロンは ( 4 ) 式と ( 5 ) 式の計算を 行うことにより, Fig. 2 の苔状線維 $(m)$ から顆粒細胞 (A)への情報処理を行っており, (5) 式の出力信号 $\left(u_{-}^{3}\right)$ は顆粒細胞 $(A)$ からの出力信号を模擬している.

\section{<第 4 層における情報処理 $>$}

第 4 層に扔ける情報処理は, $\mathrm{CMAC}$ の顆粒細胞 $(A)$ からプルキンエ細胞 $(P)$ への情報処理に対応する。つま り，(6)式により第 3 層のニューロンの出力を複数個組 み合わせて重み付き加算した後に出力する. 第 4 層の ニューロンの個数は出力変数の個数に一致する.

以上の処理により，本研究で用いたニューラルネット ワークを構成して学習を行わせることができる.つぎに， このニューラルネットワークの構造の自己選択能力につ いて述べる。

\section{3 ネットワーク構造の自己選択能力}

対象となるシステムの複雑さに適したニューラルネッ トワークの構造と規模を自己選択する場合，実際問題へ の応用を考慮してニューラルネットワークの学習に用い なかった新しいデー夕に対する適合性(汎化能力)を最も 良くするように自己選択する必要がある。本研究で用い たニューラルネットワークでは, 第 2 層の量子化係数 $(K)$ の值を徐々に増加させていき, $K$ が小さな値の学習 計算時に得られた結合荷重値を, $K$ が大きな值の学習計 算時の結合荷重值の初期値として用いることにより，よ り少ない計算量でネットワーク構造の自己選択ができる ようにした。ささらに，おの扔のの $K$ の值に対して学習に 用いなかった新しいデー夕に対する予測誤差を評価規準 として用いることにより汎化能力を評価し，この評価規 準值を最小饮するうう扔の扔のの $K$ の值に対する学 習を行った。このような処理を行うことにより過学習の 状態になることを避けて汎化能力をより大きくすること ができる。また，本研究で用いるニューラルネットワー クでは，第 2 層における苔状線維の集合 $\left(m_{i}\right)$ の構成方

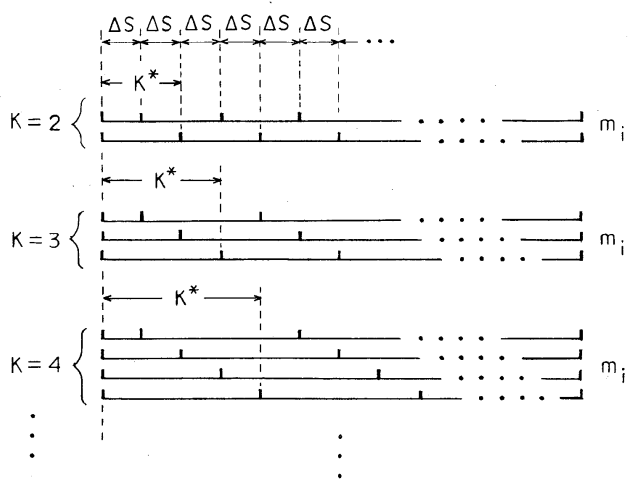

Fig. 3 Structure of mossy fiber $(m)$ when $\Delta S$ is fixed
法の違いが，ニューラルネットワークの構造と汎化能力 の大きさに影響を及ぼすために，つぎに苔状線維の集合 $\left(m_{i}\right)$ の構成方法について述べる. $m_{i}$ の構成方法として は, $\Delta S$ (量子化の最小間隔)を固定にする場合の $m_{i}$ の構 成方法と, $\Delta S$ を固定にしない場合の $m_{i}$ の構成方法の 2 種類が考えられる.Fig. 3 に $\Delta S$ を固定にする場合の $m_{i}$ の構成方法を示す.また, Fig. 4 に $\Delta S$ を固定にしない場 合の $m_{i}$ の構成方法を示す. $\Delta S$ を固定にしない場合の $m_{i}$ の構成方法では，Kの值を大きくしていくと $\Delta S$ が 小さくなるので入力ベクトル $(S)$ に対する分解能が増 加し，入力ベクトル $(S)$ の小さな信号を捕らえることが できるようになる、しかしながら，入力ベクトル $(S)$ の 信号に対して，第 2 層と第 3 層のおのおののニューロン が発火する間隔(量子化間隔 $K^{*}$ )が変化しないために, $K$ の值が大きくなるとニューラルネットワークを構成 するニューロンの個数が増加する.これに対して, $\Delta S$ を 固定にする場合の $m_{i}$ の構成方法では, 入力ベクトル (S) に対する分解能は変化しないが， $K$ の值を大きくす ると，入力ベクトル $(S)$ に対して第 2 層と第 3 層のおの おののニューロンが発火する間隔(量子化間隔 $K^{*}$ )が大 きくなるためにニューラルネットワークを構成する ニューロンの個数を大幅に減少させることができる.こ のように両方の方法ともそれぞれ特徵をもっているが, ここでは, ニューラルネットワークの規模をなるべく小 さくしたいので，Fig. 3 の $\Delta S$ を固定にする場合の $m_{i}$ の構成方法を用いて苔状線維の集合を作成する。ここで, $\Delta S$ の值は対象となるシステムの性質に依存しているた めに，ヒューリスティックスに決定することにする。 [ネットワーク構造の自己選択能力]

\section{$<K=2$ の場合の処理 $>$}

ネットワーク構造の自己選択は, 量子化係数 $(K)$ を 2 から徐々に大きくしていき，少ない計算量で予測誤差を 最も小さくするニューラルネットワークの構造を自己選

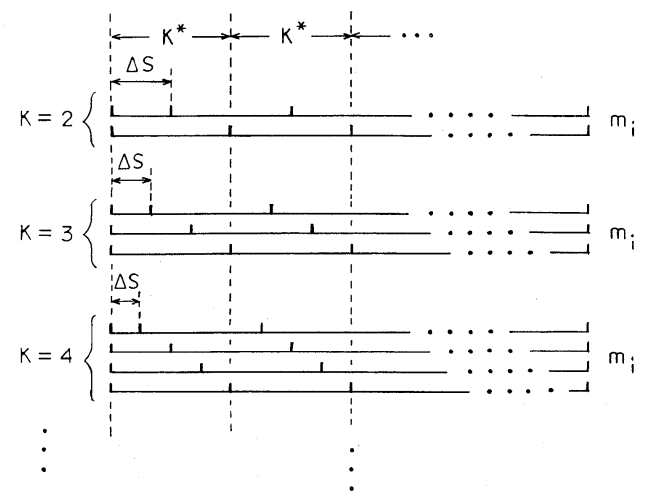

Fig. 4 Structure of mossy fiber $(m)$ when $\Delta S$ is not fixed 
択する. 以下に，自己選択の処理を具体的に示す.

まず，使用できる入出力データをニューラルネット ワークの結合荷重值の学習用データと, ニューラルネッ トワークの構造選択用データの 2 種類に分ける.つぎに, 量子化係数を $K=2$ として，ニューラルネットワークを 構成し,前述の第 1 層から第 4 層までの情報処理を行う。 このときの苔状線維の集合 $\left(m_{i}\right)$ の構成方法は, $\Delta S$ を固 定にして Fig. 3 のように行う. また, 学習回数は, 二ュー ラルネットワークの構造選択用の入出力データから計算 した汎化能力の評価規準值(たとえば, 予測值の平均二乗 誤差)を,一定の学習回数(たとえば, 1250 回)ごとに計算 して, この評価規準值が増加するときの学習回数で $K=$ 2 に対する処理を停止する。

\section{$<K$ が 3 以上の場合の処理 $>$}

$K=3$ では， $K=2$ の場合に求めたニューラルネット ワークの結合荷重值を初期值として用いて学習を行う。 具体的には，まず，第 2 層における苔状線維の構成を変 更し, $n^{3}{ }_{i}(i=1,2, \cdots, r)$ の苔状線維の集合を新しく構成 する.そして,これらの苔状線維から信号を受ける第 3 層 の顆粒細胞 (Fig. 2 の例では, $A_{q i}\left(i=1,2, \cdots, r^{2}\right)$ の顆粒 細胞) を新しく作成する。このとき，新しく作成した苔状 線維 $n^{3}{ }_{i}(i=1,2, \cdots, r)$ と最も量子化間隔が重複する苔 状線維 $n^{2}{ }_{i}(i=1,2, \cdots, r)$ に対して,この苔状線維 $n^{2}{ }_{i}(i$ $=1,2, \cdots, r)$ と顆粒細胞 $A_{p i}\left(i=1,2, \cdots, r^{2}\right)$ との結合荷 重值(具体的には，第 3 層と第 4 層の結合荷重値) を，新 しく作成した苔状線維 $n^{3}{ }_{i}(i=1,2, \cdots, r)$ と顆粒細胞 $A_{q_{i}}\left(i=1,2, \cdots, r^{2}\right)$ との結合荷重值(新しく追加した第 3 層と第 4 層のニューロンの結合荷重値)の初期值として 用いる.そして,このようにして構成した $K=3$ の場合の ニューラルネットワークの構造を用いて学習を行う。こ の場合も $K=2$ の場合と同様に，ニューラルネットワー クの構造選択用入出力データから計算した汎化能力の評 価規準值を一定の学習回数ごとに計算して，この評価規 準值が増加するときの学習回数で $K=3$ に対する処理を 停止する.ここで, $K=3$ で得られた評価規準值の最小値 が, $K=2$ で得られた評価規準値の最小值よりも増加す る場合には自己選択の処理を終了し， $K=2$ で構成した ニューラルネットワークを採用する，また，逆に評価規 準值が減少する場合には，つぎの $K=4$ の場合の処理へ 移る. $K$ の值が 4 以上の場合の処理では, $K=3$ で行った 処理と同様の処理を繰り返して適用する。ここでは，評 価規準值を計算させながら設計パラメータ(量子化係数 や学習回数)值を徐々に増加させていき,この評価規準値 が増加するときに学習処理を停止したり，また，ニュー ラルネットワーク構造の自己選択処理を停止している。 これは, 文献 4)〜7) などの同定結果から，理論的根拠は
与えられていないがこのときに評価規準值が最小值をと るものと思われ,さらにここでは小型コンピュータ(パソ コン)を用いて学習が可能なように, 学習に必要とされる 計算量をできるだけ少なくしたいので，計算の停止方法 としてこのような方法を用いた。そのほかの計算停止方 法としては，ある程度の大きさのパラメータ值(たとえ ば, $K$ は 30 程度, 学習回数は 20000 回程度)まで, 無条 件に学習計算を行い, その中で評価規準值が最小となる $K$ の值や学習回数を採用するという方法も考えられる. しかしながら，この方法では計算量が非常に多くなるた めに高速の計算機が必要となる. Fig. 5 にネットワーク 構造の自己選択手順をフローチャートで示す.

以上のネットワーク構造の自己選択の処理により，対 象システムの複雑さに適したニューラルネットワークの 構造と規模を自己選択することが可能になり, 複雑な構 造をした実システムの同定問題に対しても，実用的な予 測精度をもつニューラルネットワークを構成することが 期待できる。本研究では，ニューラルネットワークの実 際問題への応用として圧延モデル同定問題を取り上げ, 本研究で用いたニューラルネットワークの実際問題への 有効性を具体的に検討する.

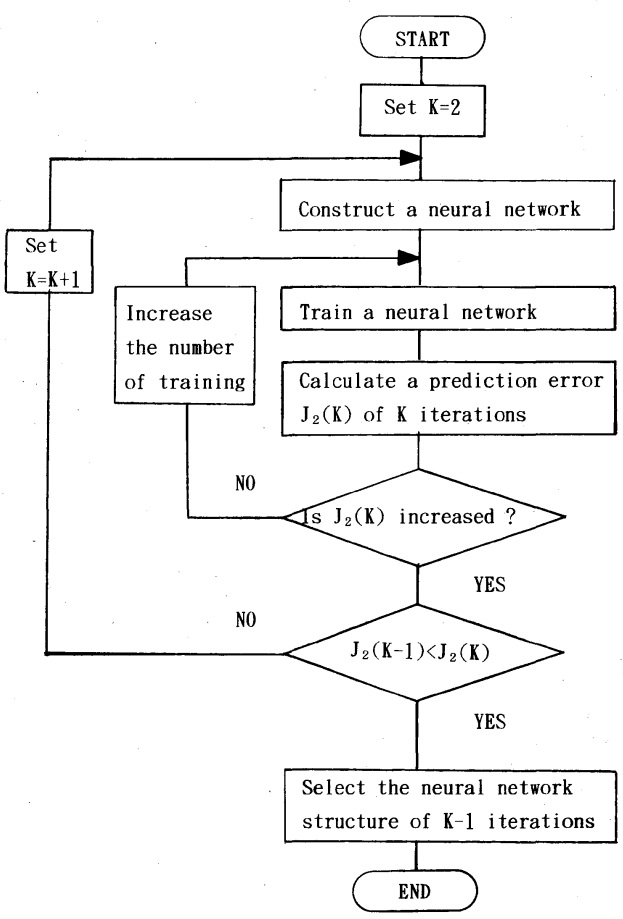

Fig. 5 Flow chart of the self-selection algorithm 


\section{3. 圧延モデル同定問題への応用}

鉄・非鉄プロセスにおける圧延システムでは，コン ピュータを用いた計算機制御システムが導入され高精度 な圧延が実施されている、コンピュータによる圧延制御 では, 非常に短い時間にダイナミックに変化する圧延状 態を正確に予測するために圧延理論に基づいた各種の物 理モデルが用いられているが，圧延される被圧延材料の 種類が非常に多く, また, 個々の被圧延材料の材質にバ ラツキがあるために，これらの被圧延材料の違いにより 圧延特性や操業方法などが微妙に異なり，物理モデルの みによって圧延状態を正確に予測することは難しい。こ のために実際のコンピュータによる圧延機の制御では, 物理モデルの予測值に対して統計モデルを用いて補正を 行ったり, 先行材の圧延デー夕の実績值から圧延時の誤 差を検出してこの值をコンピュータに記憶させ, 後続材 の圧延機の設定値計算時に物理モデルによる予測值の補 正を行うなどの操作を行い, 高精度な圧延を実現してい る.

本研究では，ネットワーク構造の自己選択能力を備え たニューラルネットワークを用いて，圧延データを学習 させる．ここでは，代表的な圧延モデルとして圧延荷重 モデルを取り上げ，圧延理論によって作成された物理モ デルのみでは十分に説明できない複雑な挙動を, ニュー ラルネットワークを用いて学習することにより同定す る.そして，物理モデルによる予測値をニューラルネッ トワークを用いて補正することにより圧延荷重モデルの 予測精度の向上を試みる。

\section{1 ニューラルネットワークによる圧延モデルの 同定}

圧延荷重モデルは一般的につぎのように表わされる.

$$
P=F_{1}\left(H, h, b, \mu, \sigma_{f}, \sigma_{b}, T, V\right)+\varepsilon
$$

ここで, $P$ は圧延荷重 (ton), $H$ は入側板厚 $(\mathrm{mm}), h$ は 出側板厚 $(\mathrm{mm}), b$ は板幅 $(\mathrm{mm}), \mu$ は摩擦係数, $\sigma_{f}$ は前 方張力 $\left(\mathrm{kg} / \mathrm{mm}^{2}\right), \sigma_{b}$ は後方張力 $\left(\mathrm{kg} / \mathrm{mm}^{2}\right), T$ は材料 温度 $\left({ }^{\circ} \mathrm{C}\right), V$ はロール周速度 $(\mathrm{m} / \mathrm{min})$ を表わす. モデル 式 $\left(F_{1}\right)$ の構造としては, 圧延理論の研究から物理モデル として Karmanの方程式や Orowan の方程式が導出さ れている.実際の圧延機の制御では, Orowan の式を簡略 化した Sims の式9) などがよく用いられる。ここでは,こ れらの物理モデルを用いては十分に説明できない挙動 (દ) をニューラルネットワークを用いて同定し，物理モ デル $\left(F_{1}\right)$ を補正することを試みる.

まずはじめに，ニューラルネットワークの入力変数に ついて検討する.ニューラルネットワークの入力変数と しては, ( 7 ) 式の物理モデルと同じく, $H, h, b, \mu, \sigma_{f}, \sigma_{b}$,
$T, V$ などの変数が考えられる.しかしながら, ニューラ ルネットワークを多くの変数を含む複雑な挙動をする実 システムへ応用する場合，実システムの特徵をネット ワークの内部に記憶させるためには多くのニューロンが 必要となり，ネットワークの規模が大規模化する傾向が ある.このために，ニューラルネットワークの入力変数 の個数はできるだけ少なくすることが望ましい.ここで は，物理モデルの入力変数をそのまま用いることは避け て,これらの変数の代わりに物理モデルによる荷重推定 值 $(\hat{P})$ をニューラルネットワークの入力変数として用 いることにする. そのほかの入力変数としては, 文献 10) に報告されている解析結果により，披圧延材料の違いを 表わす定性的変数 $(x)$ を入力変数として考慮する.これ は，実際に行われている圧延では，操業方法や圧延特性 などが，披圧延材料の種類によって異なるために，披圧 延材料の種類の違いがモデルによる圧延荷重予測值に影 響を及ぼすためである.ここでは, 定性的入力変数 $(x)$ と して披圧延材料の種類を 1 から 5 にコード化した值 $(1$ から 5 の整数值)を用いる.また, 文献 10)では, 定性的 入力変数 $(x)$ とともに板幅 $(b)$ とロール周速度 $(V)$ が 重要な働きをしていることが報告されている，このため に，本研究においてもこれらの変数を入力変数として用 いる. 以上のことから，ニューラルネットワークの入力 変数としては, $\hat{P}, x, b, V$ の 4 変数とする.本研究に扔い て同定する圧延荷重モデルは,

$$
\begin{aligned}
P= & F_{1}\left(H, h, b, \mu, \sigma_{f}, \sigma_{b}, T, V\right) \\
& +F_{2}(\hat{P}, x, b, V)+\varepsilon^{\prime}
\end{aligned}
$$

のように表わされる.ここで， $F_{1}$ は物理モデル， $F_{2}$ は ニューラルネットワークを用いて同定するモデル， $\varepsilon^{\prime}$ は まったくランダムな挙動を表わす。ここで, 本研究で使 用するニューラルネットワークの入出力変数用のデー夕 として, 1 本のコイルについて, $P, x, b, V$ の圧延実績值 と,さらに物理モデルによる荷重推定值 $(\widehat{P})$ の合計 5 種 類のデータが求められている. そして, 学習用に 25 本分 のコイルのデータが，また，予測誤差の評価用に別の 25 本分のコイルのデータが準備されている.

本研究で使用するニューラルネットワークでは，第 2 層において入力変数の量子化操作を行う．圧延モデル同 定で用いる入力変数はそれぞれ単位が異なるために，こ こでは, 入力データの前処理を以下のようにして行い, 入力変数の無次元化と規準化を行う.

$$
\begin{aligned}
& \widehat{P}^{\prime}=\frac{\hat{P}}{\widehat{P}_{\max }} \\
& x^{\prime}=\frac{x}{5}
\end{aligned}
$$




$$
\begin{aligned}
& b^{\prime}=\frac{b}{b_{\max }} \\
& V^{\prime}=\frac{V}{V_{\max }}
\end{aligned}
$$

ここで, $\hat{P}_{\max }$ は荷重推定値の最大值, $b_{\text {max }}$ は板幅最大值, $V_{\max }$ はロール周速度最大值を表わす. 入力デー夕の前処 理を行うことにより作成される新しい変数 $\hat{P}^{\prime}, x^{\prime}, b^{\prime}, V^{\prime}$ は 0 から 1 までの値をとるために，量子化操作を容易に 行うことができる.また, (2) 式に打ける入力変数の 2 次 の項(非線形項) として, 対象システムの知識に基づいて 入力変数のいくつかの組合せを検討した結果, 変数 $\bar{P}^{\prime} \cdot V^{\prime}$ を力ベクトル $(S)$ として考慮した場合に汎化 能力が大きくなることがわかったので，本研究では変数 $\hat{P}^{\prime} \cdot V^{\prime}$ のみを非線形項として考慮することにする。ま た, 同定に用いるパラメータとしては, $\Delta S=0.1$, 学習係 数 $=0.01$ とする.

\section{2 ニューラルネットワークによる同定結果}

まず，同定結果の評価方法について述べる。ニューラ ルネットワークによって得られた同定結果の評価を行う ために, 学習に用いたデータに対する精度(同定精度)と， 未学習の新しいデー夕に対する精度 (予測精度)を次式に よって評価する。

\section{(同定精度)}

学習に用いた 25 本分のコイルの入出力データを用い て求める.

$$
J_{1}=\frac{1}{25} \sum_{i=1}^{25} \frac{\left|\hat{P}_{i}-P_{i}\right|}{b_{i}}
$$

ここで, $P_{i}$ は圧延荷重, $\widehat{P}_{i}$ は物理モデルとニューラル ネットワークによる圧延荷重推定值， $b_{i}$ は板幅を表わ す.

\section{（予測精度）}

学習に用いなかった新しい 25 本分のコイルの入出力 データを用いて求める.

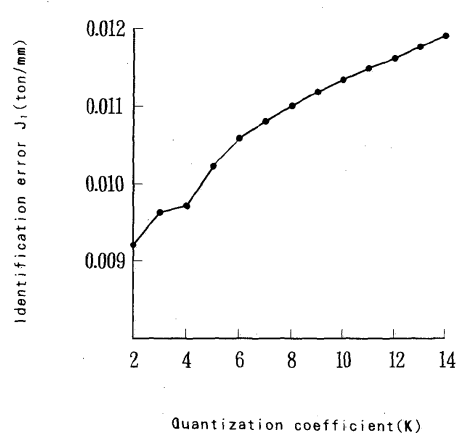

Fig. 6 Identification error for various quantization coefficients $(K)$

$$
J_{2}=\frac{1}{25} \sum_{i=26}^{50} \frac{\left|\hat{P}_{i}-P_{i}\right|}{b_{i}}
$$

ここで, $P_{i}$ は圧延荷重, $\widehat{P}_{i}$ は物理モデルとニューラル ネットワークによる圧延荷重予測值， $b_{i}$ は板幅を表わ す.

以下に同定結果を示す.まず, 量子化係数 $(K)$ の值が 2 から 14 まで徐々に増加したときの同定精度 $\left(J_{1}\right)$ の変 化を Fig. 6 に，また予測精度 $\left(J_{2}\right)$ の変化を Fig. 7 に示 す. Fig. 6 より, 量子化係数 $(K)$ の值が大きくなると $J_{1}$ は徐々に増加することがわかる.つぎに, Fig. 7 より $J_{2}$ は $K=9$ のときに最小になることがわかる，このときの 最小值は $J_{2}=0.0207(\mathrm{ton} / \mathrm{mm})$ となった.ここでは, $J_{2}$ の値が $K=9$ で最小になることを確認するために, 評価 規準值が増加するところ $(K=10)$ で計算を停止せずに, $K=14$ まで計算を続けて $J_{2}$ の変化を調べた. Table 1 に, ニューラルネットワークの各層におけるニューロン の個数を示す.ここで, Table 1 の第 1 層および第 2 層に おけるニューロンの個数には，Fig. 1 における $\theta_{0}$ と $\theta_{1}$ を入力とするニューロンを含めている．また，各層にお けるニューロンの個数は以下のようになる.

<第 1 層におけるニューロンの個数 >

(入力変数の個数) +1

<第 2 層におけるニューロンの個数 $>$

(入力ベクトルの 1 変数当たりの分割数 $(r)) \times($ 量子化 係数 $(K)) \times($ 入力ベクトルを構成する変数の個数 $)+1$ ＜第 3 層におけるニューロンの個数 $>$

(入力ベクトルの 1 変数当たりの分割数 $(r))^{2} \times($ 量子化

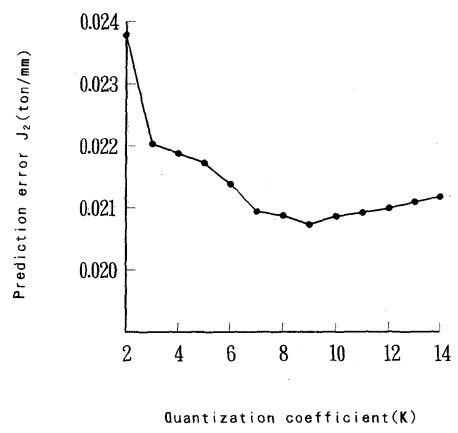

Fig. 7 Prediction error for various quantization coefficients $(K)$

Table 1 Number of neurons in each layer

\begin{tabular}{c|r|r|r|r|r}
\hline Layer & $K=2$ & $K=4$ & $K=6$ & $K=8$ & $K=10$ \\
\hline 1 & 5 & 5 & 5 & 5 & 5 \\
2 & 61 & 81 & 91 & 81 & 86 \\
3 & 720 & 640 & 540 & 320 & 310 \\
4 & 1 & 1 & 1 & 1 & 1 \\
\hline
\end{tabular}


係数 $(K)) \times($ 入力ベクトルの相異なる 2 変数の組合せ

数)

<第 4 層におけるニューロンの個数>

(出力変数の個数)

たとえば， $K=2$ の場合には，

＜第 1 層におけるニューロンの個数＞

$4+1=5$ 個

<第 2 層におけるニューロンの個数 $>$

$6 \times 2 \times 5+1=61$ 個

＜第 3 層におけるニューロンの個数 >

$6^{2} \times 2 \times{ }_{5} \mathrm{C}_{2}=720$ 個

<第 4 層に抢けるニューロンの個数 $>$

1 個

となった.ここで, 入力ベルトル $(S)$ は $\hat{P}^{\prime}, x^{\prime}, b^{\prime}, V^{\prime}$, $\hat{P}^{\prime} \cdot V^{\prime}$ の 5 個の変数から構成される. また, 入力ベクト ルの 1 変数当たりの分割数 $(r)$ は, Fig. 2 で示した記号 $r$ を示す. 表より, 量子化係数 $(K)$ の值が大きくなると, ニューラルネットワークの中に含まれるニューロンの個 数が減少することがわかる. 以上の同定結果をまとめる と，まず $J_{1}$ に関しては，Kの值が小さいときには, ニューラルネットワークに含まれるニューロンの個数が 増加するために学習に用いたデータに対するあてはまり が良くなり, 逆に $K$ の值が大きくなると, ニューラル ネットワークに含まれるニューロンの個数が減少するた めに，学習に用いたデー夕に対するあてはまりが悪く

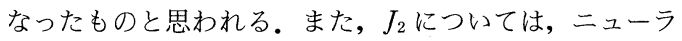
ルネットワークに含まれるニューロンの個数が適切な個 数になったときに最小值になったものと思われる。 J J ある $K$ の值に対して, 最小值をとる理由としてはつぎの ことが考えられる.まず，二ューロンの個数が多くなり すぎてニューラルネットワークの構造が必要以上に複雑

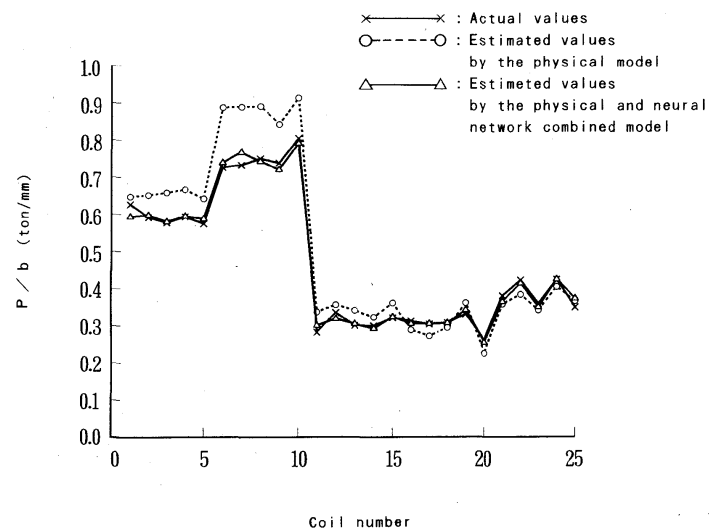

Fig. 8 Estimated values by the physical-neural network combined model
化されると, 学習に用いたデー夕に対して, 過度にあて はまってオーバーフィットの状態になり, 学習に用いな かった新しいデータへの適合性 (汎化能力) が小さくなる ことにより良い予測精度が得られなくなる. また, 逆に ニューロンの個数が少なすぎてニューラルネットワーク の構造が十分な複雑さをもっていない場合には, 対象シ ステムの特徴を十分に同定できないために, 学習に用い たデー夕に対して十分なあてはまりができず，また，学 習に用いなかった新しいデータへの適合性 (汎化能力) も 十分でないことにより良い予測精度が得られなかったも のと思われる。

以上の同定結果により, 量子化係数 $(K)$ の最適値とし て $K=9$ が求まった。 また，このときの精度は， $J_{1}=$ $0.0112(\mathrm{ton} / \mathrm{mm}), J_{2}=0.0207(\mathrm{ton} / \mathrm{mm})$ となった。ここ で, 物理モデルとニューラルネットワークを組み合わせ た物理・ニューラルネットワーク混合モデルにより得ら れた予測值を示す. Fig. 8 は学習に用いたデー夕に対す る推定值を, Fig. 9 は学習に用いなかった新しいデー夕 に対する予測値をそれぞれ示す．物理モデルのみを用い た場合に比べて，大幅に精度が改善されていることがわ かる。

\section{3 従来から用いられてきた GMDH 手法による 同定結果 ${ }^{10)}$}

物理モデルと統計的非線形システム同定手法 $(\mathrm{GMDH}$ 手法)を組み合わせた，物理・統計混合モデルを用いた圧 延モデル同定方法が提案されている ${ }^{10)}$.ここでは,この物 理・統計混合モデルによって得られた同定結果と 3.2 節 で述べた物理・ニューラルネットワーク混合モデルに よって得られた同定結果との比較を行う。なお，物理・ 統計混合モデルは文献 10)に詳しく報告されているの で，ここでは文献 10)から同定結果を引用する。

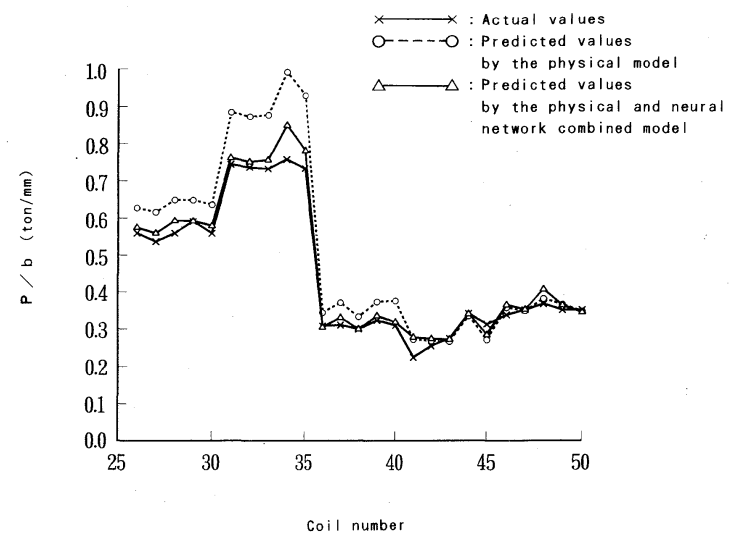

Fig. 9 Predicted values by the physical-neural network combined model 


\section{[数量化入力変数を用いる GMDH による同定結果]}

文献 10)より，定性的入力変数を取り扱うことができ るようにアルゴリズムに改良を加えた数量化入力変数を 用いる GMDH による同定結果を示す。この GMDH で は, 入力層に扔いて定性的入力变数の数量化処理を行い 数量化入力変数を作成している.このために, GMDH の 入力変数としては, 定量的入力変数として, $H, h, b, \mu$, $\sigma_{f}, \sigma_{b} T, V$ の 8 変数を, また, 定性的入力変数として, 5 種類の被圧延材料に対するダミ一変数 $\left(x_{11}, x_{12}, x_{13}\right.$, $\left.x_{14}, x_{15}\right)$ の 2 種類の入力変数を用いている. 文献 10)の GMDH を用いた同定では，ニューラルネットワークの 場合と同様に $(8)$ 式の $F_{2}$ に相当する部分の同定を行っ ている.ただし, GMDH とニューラルネットワークでは $F_{2}$ の部分の入力変数が異なっている.

\section{(同定されたモデル式)}

第 4 層を通過してつぎのモデル式が得られた。

$$
\begin{aligned}
& F_{2}=-8.040+0.0000355 b V x_{1}-1.483 x_{1} \\
& x_{1}=21.2-76.6 x_{12}-157.4 x_{13}-56.6 x_{14}-4.2 x_{15}
\end{aligned}
$$

ここで， $x_{1}$ は 5 種類の被圧延材料に対するダミ一変数か ら構成された数量化入力変数を表わす。

\section{(同定精度)}

モデルの同定に用いた 25 本分のコイルのデータに対 する同定精度を示す.同定精度は（13）式により評価する。

$$
J_{1}=0.015 \mathrm{ton} / \mathrm{mm}
$$

となった。

\section{(予測精度)}

モデルの同定に用いなかった 25 本分のコイルのデー 夕に対する予測精度を示す。予測精度は（14）式により評 価する。

$$
J_{2}=0.026 \mathrm{ton} / \mathrm{mm}
$$

となった。

数量化入力変数を用いる GMDH では，モデル式の中 に定性的入力変数を取り込むことができるために，同定 されたモデル (15)式の構造は大幅に簡素化されている.

\section{4 同定結果のまとめ}

ニューラルネットワークと数量化入力変数を用いる改 良形 GMDH によって得られた同定結果を以下にまとめ る.なお， Table 2 にこれらの手法により得られた精度を まとめて示す。

（1）ニューラルネットワークの同定結果より， ニューラルネットワークでは構造パラメー夕(量子化係 数 $K$ )をどのような值に設定するのかにより得られる精 度は大きく变化する，学習に用いたデー夕に対する精度 (同定精度 $J_{1}$ ) は，ネットワークの規模を大きくしてネッ トワークの構造をより複雑にすると良くなる。これに対
Table 2 Accuracy of the prediction models

\begin{tabular}{c|c|c}
\hline \hline Type of model & $J_{1}$ (ton $\left./ \mathrm{mm}\right)$ & $J_{2}$ (ton $\left./ \mathrm{mm}\right)$ \\
\hline Neural Network & 0.011 & 0.021 \\
GMDH & 0.015 & 0.026 \\
\hline
\end{tabular}

して,学習に用いなかった新しいデータに対する精度(予 測精度 $J_{2}$ ) は，適切なネットワーク規模のときに最小値 をとる。このために，ニューラルネットワークの実際問 題への応用を考えた場合，汎化能力を最も大きくする ニューラルネットワーク，つまり予測精度を最も良くす るニューラルネットワークを構成することが重要である ために，予測精度を用いたニューラルネットワーク構造 の自己選択能力が非常に重要であることがわかる。本研 究では, 圧延モデル同定に適したネットワーク構造を予 測精度 $\left(J_{2}\right)$ を評価規準として用いて自己選択すること により，実用的な精度を得ることができた。

（2）ニューラルネットワークと数量化入力変数を用 いる改良形 GMDH との比較では, ニューラルネット ワークの同定精度 $\left(J_{1}\right)$ と予測精度 $\left(J_{2}\right)$ は $\mathrm{GMDH}$ の精 度と比較して大幅に改善された。これにより，精度に関 してはニューラルネットワークのぼうが数量化入力変数 を用いる改良形 GMDH よりもすぐれているといえる。

\section{4. あとがき}

本研究では，対象分野に適したニューラルネットワー クの構造を自己選択する能力を備えたニューラルネット ワークについて述へ，実際問題への応用として圧延モデ ル同定問題へ応用した，圧延モデルの同定では，圧延理 論から導かれた物理モデルと，ネットワーク構造の自己 選択能力を備えたニューラルネットワークを用いて，物 理・ニューラルネットワーク混合モデルを作成した。そ して，物理モデルと統計的非線形システム同定手法であ る GMDH 手法を用いた, 物理・統計混合モデルにより得 られた同定結果との比較を行った。その結果，同定精度 および予測精度の両方の精度に対して，物理・ニューラ ルネットワーク混合モデルのほうが，物理・統計混合モ デルよりもすぐれていることがわかった。これにより， 従来手法と比較してすぐれて抒り，しかも，実用的な予 測精度が得られていることが確かめられた。さらに， ニューラルネットワークは, 压延ラインから得られる圧 延デー夕(実績值)をオンライン状態で学習することがで き，刻々と変化する圧延状態に適応する能力にすぐれて おり，実用面でも GMDH と比較してすぐれているよう に思われる。

以上の結果により，本研究で用いたニューラルネット ワークの実際問題(圧延モデル同定問題)への有効性が 
確認できた.

\section{参 考 文 献}

1） 甘利, 後藤 (編)：人工ニューラルシステム, bit 臨時増刊 号，共立出版，21-11(1989)

2）杉江，ほか(編)：ニューロコンピュータ, partII，コン ピュートロール，コロナ社，29(1990)

3）松岡, ほか：ニューロコンピューティング, 朝倉書店 (1992)

4）近藤：複雑な構造をした非線形システムの同定を目的と したニューラルネットワーク,システム制御情報学会論文 誌, 4-7, 259/266(1991)

5）近藤：非線形システムの同定を目的としたニューラル ネットワークによる加熱炉ヒートパターンの同定, システ 么制御情報学会論文誌，6-5，223/232(1993)

6）近藤：ニューラルネットワークを用いた大気污染濃度の 短期予測, 計測自動制御学会論文集, 29-6, 710/718(1993)

7）近藤：ニューラルネットワークを用いた広域大気污染濃 度パターンの同定, システム制御情報学会論文誌，7-2, 59/67 (1994)

8) J.S. Albus(小杉, ほか(訳))：ロボティクス, 啓学出版 (1984)

9）日本鉄鋼協会圧延理論部会(編)：板圧延の理論と実際, 日 本鉄鋼協会特別報告書, 36(1984)
10）近藤，江連，安部：数量化入力変数を用いる改良形 GMDH とその圧延モデル同定への応用，計測自動制御学 会論文集，20-11，986/992(1984)

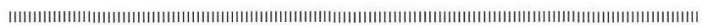

\section{[著 者 紹 介]}

近 藤正（正会員）

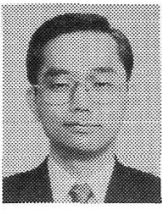

1974 年徳島大学工学部精密機械工学科 卒業, 79 年大阪大学大学院工学研究科博士 課程後期課程修了。同年(株) 東芝入社, 88 年徳島大学医療技術短期大学部助教授, 現 在に至る、システム同定，エキスパートシ ステム，ニューラルネットワーク，医療情 報シスラム，医用画像認識の研究などに従 事(工学博士)。システム制御情報学会, 電 子情報通信学会, 日本機械学会, 日本医療 情報学会, 日本医用画像工学会, 医用画像 情報学会, コンピュータ支援画像診断学会 などの会員

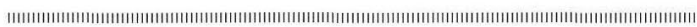

